\title{
Depicting the Heavens: The Use of Astrology in the Frescoes of Renaissance Rome ${ }^{1}$
}

\section{Emily Urban}

\begin{abstract}
This paper explores the use of astrological imagery in four ceiling frescoes painted during the Renaissance in Rome: the scenes of the Sala di Galatea in the Villa Farnesina, and those of the Stanza della Segnatura, the Sala dei Pontefici, and the Sala Bologna, all within the Vatican Palace. Significantly this imagery was not confined to the pages of private manuscripts as it had been in the Middle Ages, but took the form of frescoes on the walls and ceilings of public rooms, allowing viewers to bask in the celestial glory of the patron. Commissioned in 1575 by Pope Gregory XIII, I argue that the Sala Bologna imagery represents a critical juncture in attitudes toward natural philosophy, and demonstrates a shift from astrological interpretation, as condemned at the Council of Trent, to astronomical calculation, as promoted by the Catholic Church. I argue that the placement of these murals demonstrates that this type of pictorial aggrandizement was intended to reach a wide audience and was used by the patron, popes being the most prominent among these, as a form of visual self-promotion. I also examine how contemporaneous events - notably the Protestant Reformation and the Council of Trent - affected astrological practice and the monumental display of these horoscopes. Astrological imagery is not limited to Rome, but the four examples I discuss represent the peak of such decoration and offer insight into a widespread feature of early modern Italian culture that has yet to be adequately explored.
\end{abstract}

In 1510 Baldassare Peruzzi was charged with the task of giving visual form to the horoscope of his Sienese patron Agostino Chigi, banker and confidant of Pope Julius II, in his newly built villa located along the banks of the Tiber River in Rome. Peruzzi's ceiling in the Sala di Galatea is arguably the grandest astrological depiction of the Renaissance; illustrated in allegorical form are the seven planets and twelve zodiacal constellations as they appeared in the sky over Siena at

\footnotetext{
1 Special thanks to the Samuel H. Kress Foundation and the Bibliotheca Hertziana, as well as Dr. Antonio Paolucci and the Archivio Fotografico Vaticano, and especially Dr Rosanna di Pinto and Dr Maria Serlupi Crescenzi for their kind assistance, as always.
}

Emily Urban, 'Depicting the Heavens: The Use of Astrology in the Frescoes of Renaissance Rome', eds. Nicholas Campion and Rolf Sinclair, Culture and Cosmos, Vol. 16 nos. 1 and 2, 2012, pp. 319-330.

www.CultureAndCosmos.org 
320 Depicting the Heavens: The Use of Astrology in the Frescoes of Renaissance Rome

Chigi's birth. ${ }^{2}$ Although this example is one of the most accurate and monumental displays of astrology to ever appear in fresco, it was certainly not the first, and was by no means the last.

Developed in antiquity, maintained through the Middle Ages, and revived in the Renaissance, the illustration of astrological motifs has a long and impressive heritage, and the study of such imagery offers valuable insight into a widespread feature of early modern Italian culture. Beginning with Chigi's villa as an introduction to this type of decoration, this paper will explore the history and tradition of celestial imagery in sixteenth-century Rome by focusing on three examples within the Vatican Palace: Raphael's allegory of Astronomia located on the ceiling of the Stanza della Segnatura for Pope Julius II; Pope Leo X's Sala dei Pontefici; and Pope Gregory XIII's Sala Bologna. The frescoes to be considered have previously been treated only in isolation (or not at all); it is my belief that their examination together will shed new light on both the iconography and function of each. As the following discussion will show, each example contains an allusion to the patron's horoscope as a way of celebrating his divinely sanctioned success, albeit in vastly different pictorial forms.

\section{The Villa Farnesina}

In 1934 Fritz Saxl was the first to recognize that the scenes painted on the ceiling of the Sala di Galatea were not arbitrary mythological subjects but were instead specific allegories representing the papal banker's natal horoscope (Figure 1). ${ }^{3}$ Further, based on the precise organization of the fresco, Saxl was able to estimate the date and time of Chigi's birth as on or around the evening of 1 December 1466. Ingrid Rowland's discovery in 1984 of an entry within the Siena baptismal records confirmed the relative accuracy of these estimations. ${ }^{4}$ Since these calculations, much has been written on the iconography, composition, and astrological

\footnotetext{
${ }^{2}$ For Chigi's birth, over which much has been written, see Ingrid Rowland, 'The Birth Date of Agostino Chigi: Documentary Proof', Journal of the Warburg and Courtauld Institutes 47 (1984), p. 192. The seven planets as considered in the Renaissance include the first five of our solar system (Mercury, Venus, Mars, Jupiter, and Saturn) as well as the Sun and the Moon.

${ }^{3}$ Fritz Saxl, La Fede Astrologica di Agostino Chigi: Interpretazione dei dipinti di Baldassare Peruzzi nella Sala di Galatea della Farnesina (Rome: Reale Accademia d'Italia, 1934), p. 65.

${ }^{4}$ Saxl, Interpretazione dei dipinti, p. 65.
} 
method of Peruzzi's fresco, providing a corpus of literature on Renaissance celestial decoration. ${ }^{5}$ For this reason, and the fact that an entire natal chart is displayed in a relatively simple and clear manner, the Sala di Galatea provides an excellent paradigm in Rome from which to start and compare similar imagery.

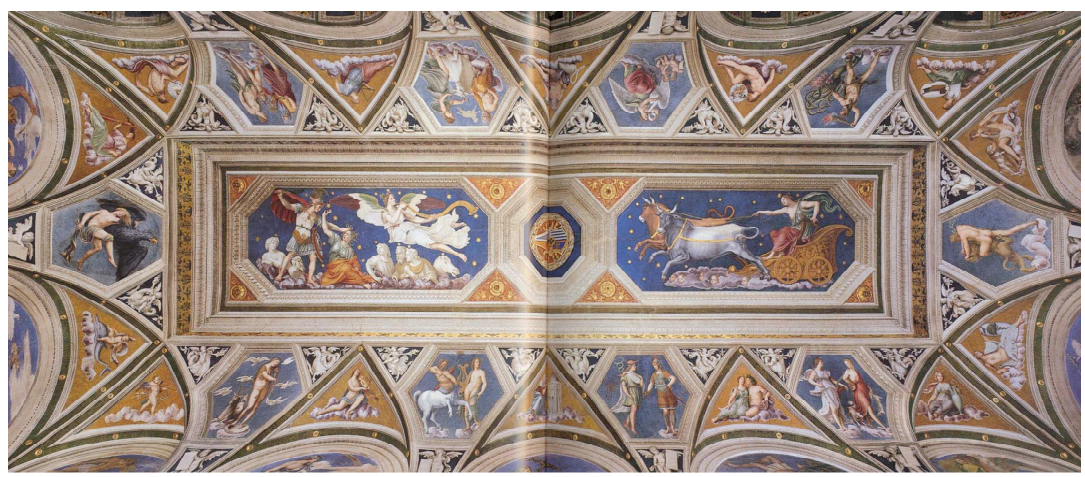

Figure 1. Baldassare Peruzzi, ceiling of the Sala di Galatea. Commissioned by Agostino Chigi, 1510, Villa Farnesina, Rome. Fresco. (photo: Archivio Fotografico, Musei Vaticani)

Beginning at the bottom left and reading clockwise are the twelve signs of the zodiac represented in ten spandrels. The two large scenes within the centre - Perseus with Fame on the left and Ursa Major on the right are essential clues in deciphering the organization of the fresco; because Ursa Major is a prominent northern constellation and Perseus lights up the southern horizon, these two panels orient the viewer to a correct axial reading of the ceiling.

The key to interpreting Peruzzi's fresco as a record of time is the location of the seven planets within the painted zodiac; because there are only a few days in history that match this exact cosmological positioning, Saxl was able to arrive at Chigi's birth date. Peruzzi arranged the

\footnotetext{
${ }^{5}$ See especially Kristen Lippincott, 'Two Astrological Ceilings Reconsidered: The Sala di Galatea in the Villa Farnesina and the Sala del Mappamondo at Caprarola', Journal of the Warburg and Courtauld Institutes 53 (1990), esp. pp. 185-96; Mary Quinlan-McGrath, 'The Astrological Vault of the Villa Farnesina: Agostino Chigi's Rising Sign', Journal of the Warburg and Courtauld Institutes 47 (1984): pp. 91-105; and McGrath, 'The Villa Farnesina, Time-Telling Conventions and Renaissance Astrological Practice', Journal of the Warburg and Courtauld Institutes 58 (1995): pp. 53-71.
} 
322 Depicting the Heavens: The Use of Astrology in the Frescoes of Renaissance Rome

horoscope so that it would be oriented for the incoming visitor when entering through the garden, and through his clever composition and precise organization he was also able to emphasize the most significant elements of Chigi's nativity. Any learned visitor entering for one of the many lavish banquets held in the room would have immediately recognized the implication of this ceiling - that the banker's success was predetermined by the heavens that had smiled upon him with a great birth.

\section{Raphael's Allegory of Astronomia}

Commissioned by Julius II, Raphael began his work in the Stanza della Segnatura in 1508. Within the corners of this ceiling he painted four scenes that help unify the room's thematic program of the liberal arts: the image of Apollo and Marsyas refers to poetry; the Fall of Man to theology; the Judgment of Solomon to jurisprudence; and lastly, the allegory of Astronomia to natural philosophy. ${ }^{6}$

Flanked on either side by cherubs and floating in front of a luminous gold background to reference the divine realm, Astronomia is seen as a beautiful young maiden clothed in billowing green drapery (Figure 2). With left arm raised, she gazes down at the universe held in her right hand. According to Aristotelian theory still upheld at the time, eight crystalline spheres containing the known planets, the sun, the moon, and the stars encircled and rotated around the fixed Earth at the centre. Unlike other illustrations that depict this concept as a series of concentric circles in a flattened diagram, Raphael chose to paint his universe in a spatially realistic way and was thus confronted with the artistic challenge of representing eight transparent spheres surrounding an opaque Earth.

\footnotetext{
${ }^{6}$ For a different interpretation of these corner panels as representing the four elements, see Edgar Wind, 'The Four Elements in Raphael's Stanza della Segnatura', Journal of the Warburg and Courtauld Institutes 2 (1938-39): pp. 75-9. The allegory's identification as 'Astrologia' begins with Vasari. See also Christine Joost-Gaugier, Raphael's Stanza della Segnatura: Meaning and Invention (Cambridge: Cambridge University Press, 2002), p. 52; and Nancy Rash-Fabbri, 'A Note on the Stanza della Segnatura', Gazette des Beaux-Arts 94 (1979): p. 100; Kristen Lippincott, 'Raphael's “"Astronomia”: Between Art and Science', in Robert G.W. Anderson, James A. Bennett and W.F. Ryan (eds.), Making Instruments Count: Essays on Historical Scientific Instruments (Aldershot: Variorum, 1993), p. 76. For simplicity's sake, I have chosen to label this allegory as Astronomia.
} 
Samuel Edgerton Jr. argues that the artist's solution was to portray the Earth surrounded by only the outermost sphere, that of the fixed stars. ${ }^{7}$

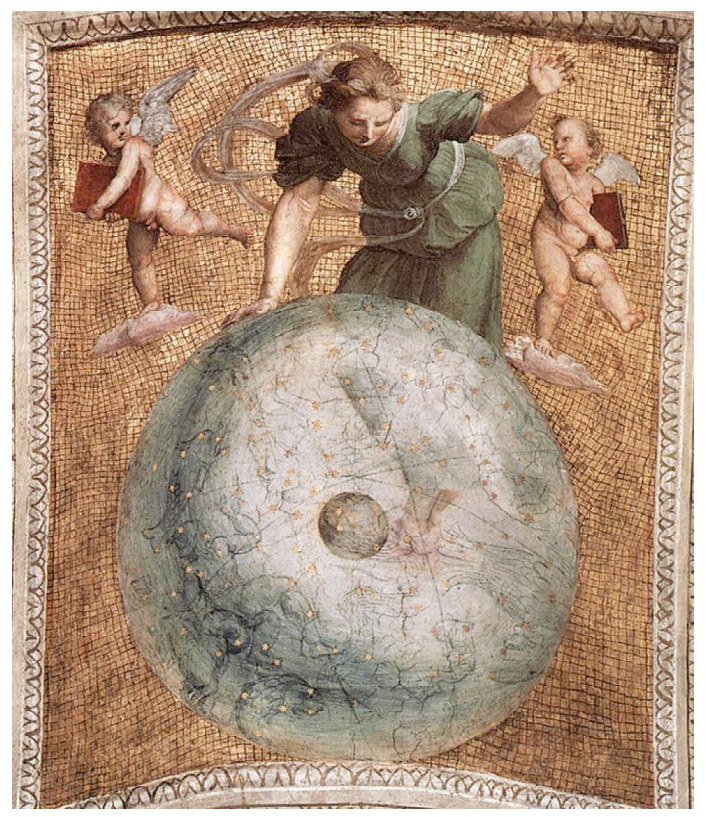

Figure 2. Raphael, Astronomia. Commissioned by Pope Julius II, 1508, Stanza della Segnatura, Vatican Palace, Rome. Fresco. (photo: Archivio Fotografico, Musei Vaticani)

Beginning with Draco at the top of the globe and moving in a clockwise direction are the constellations Cepheus or Andromeda, Pisces, Cetus, Pisces Meridionalis, Capricorn, Aquarius, Delphinus, Lyra, and Pegasus. ${ }^{8}$ Of the forty-eight constellations that fill the sky, why portray these specific ten? Scholars argue that the organization of this fresco conveys a personal astrological meaning. Because there are no planets present, a

\footnotetext{
${ }^{7}$ Samuel Y. Edgerton, The Heritage of Giotto's Geometry: Art and Science on the Eve of the Scientific Revolution (Ithaca: Cornell University Press, 1991), $\mathrm{p}$. 205. A drawing now in the Albertina Gallery in Vienna (Bd. IV, 188) demonstrates that Raphael's original model for such an innovative depiction was an armillary sphere, on which see esp. Lippincott, 'Between Art and Science', 1993, p. 85.

${ }^{8}$ Rash-Fabbri, 98, was the first to identify the constellations. I am here working with the slightly modified version from Lippincott, 'Between Art and Science', p. 77.
}

Culture and Cosmos 
324 Depicting the Heavens: The Use of Astrology in the Frescoes of Renaissance Rome

specific date or time cannot be calculated; however, the emphasis given to Pegasus, located just above the Earth in the centre of Raphael's universe, is significant when considered within the context of Julius' papacy. In the autumn months between September and November, the winged horse lights up the night sky at the latitude of Rome, and thus its prominence here provides a reference to the pope's election on 31 October 1503.

In this allusion to autumn, Raphael surrounded Pegasus by its celestial neighbours. Several other constellations border the horse however, including Aries, Cygnus, Perseus, and Cassiopeia, among others. What then, if anything, can be said in regards to the nine constellations represented here? I would like to suggest that the deliberate inclusion of the water signs-Pisces, Pisces Meridionalis, Aquarius, Delphinus, and the emphatic illustration of Aquarius' stream-is significant. Roughly contemporaneous with the decoration of this stanza was Julius' early success with the League of Cambrai in the battle against Venice, including the regaining of control over the lost territory of Rimini. Although eventually a failure with its end in 1516, the League at the time of Raphael's fresco progressed towards the pope's ultimate goal of control over the watery lagoon. The portrayal of these aquatic constellations might, therefore, refer to this important military campaign.

Finally, I would like to turn to the sign of Capricorn on the bottom left of the globe. A depiction of the autumnal sky need not include this constellation and yet it is here so deliberately illustrated in the corner that its inclusion certainly bears significance. In his description of the zodiacal constellations, most of which he says gaze towards each other, Manilius writes of the goat, 'Capricorn on the other hand turns his gaze upon himself (what greater sign can he ever marvel at, since it was he that shone propitiously upon Augustus' birth?)'. ${ }^{9}$ As is well known, Julius strove earnestly to revive the glory of ancient Rome in his own day, and what better way to allude to this idea and link the pope to the greatest of the Caesars than to represent the ascendant sign of Augustus on the ceiling of his personal study?

If the above hypotheses are correct, then through the use of astrology Raphael, within this one small fresco in the corner, was able to celebrate Julius' elevation to the papacy, to glorify the pope's early

\footnotetext{
${ }^{9}$ Marcus Manilius, Astronomica, trans. G.P. Goold, Cambridge Mass. (London: Harvard University Press, 1977), Book 2, lines 509-12.
} 
victories against the Venetian Republic, and to liken him to the first and greatest of emperors in ancient Rome.

\section{The Sala dei Pontefici}

Julius' successor Leo $\mathrm{X}$ also incorporated astrological imagery into his rooms within the Vatican Palace. The Sala dei Pontefici, an audience chamber located in the last room of the Borgia suites, was commissioned c. 1521 by Perino del Vaga and Giovanni da Udine. In contrast to its model in the Villa Farnesina is the organization of the pope's ceiling; rather than the accurate arrangement of his horoscope, the elements of Leo's natal chart have been manipulated in their positioning in order to showcase specific aspects (Figure 3).

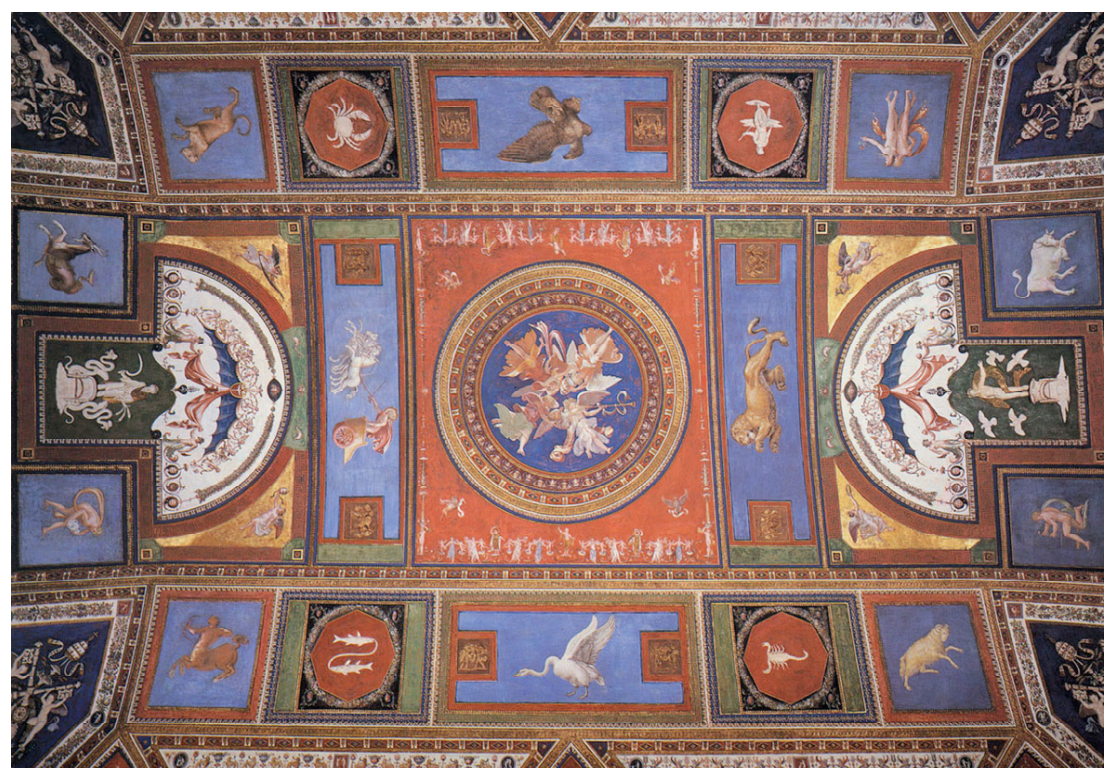

Figure 3. Perino del Vaga and Giovanni da Udine, ceiling of the Sala dei Pontefici. Commissioned by Pope Leo X, c. 1521, Vatican Palace, Rome. Fresco. (photo: Archivio Fotografico, Musei Vaticani)

Perhaps most noteworthy in this respect is the central placement of the Sun and the constellation Leo. In addition to referencing Rome (based on the city's foundation date in antiquity), the Sun and the lion glorify the namesake of Leo, as it is on account of this inherent astrological link to Rome that the Medici pope chose his papal name. Additionally, the leonine constellation shines brightly overhead during March, the month 
326 Depicting the Heavens: The Use of Astrology in the Frescoes of Renaissance Rome

of Leo's ascension to the papacy, and indeed this reference to such a divine election can be found within his other commissions, including the borders of the Sistine Chapel Tapestries.

As the son of Lorenzo the Magnificent de'Medici, who invited several astrologers into his court, Leo would have been exposed to the practice of astrology at an early age; in fact it was during his tenure within the Medici household that the famed Renaissance astrologer Marsilio Ficino first foretold the election of the future pope. ${ }^{10}$ The decoration of the Sala dei Pontefici suggests that Leo took this prophecy to heart and, similar to Agostino Chigi, commissioned a ceiling that displayed in pictorial form the notion that his ascension to power was astrologically predestined. Moreover, as Claudia Rousseau has noted, at the time of this commission Leo was attempting to overcome criticism of his controversial involvement with the election of the new Holy Roman Emperor, as well as his poor handling of the growing Protestant Reformation. ${ }^{11}$ Such a large demonstration of celestial preordination might have been an effort to excuse criticism by demonstrating the pope's fate and actions as celestially predetermined and thus, to some extent, out of his control. In other words, it was the Renaissance equivalent of good publicity.

\section{The Sala Bologna}

Decorated in 1575 for Gregory XIII and situated in the northern wing of the Vatican Palace, the Sala Bologna contains a brilliant rendition of the heavens designed by the Lombard artist Giovanni Antonio Vanosino da Varese (Figure 4). Below the celestial map is a fictive colonnade painted by Ottaviano Mascherino, in which sit ten ancient astronomers painted by Lorenzo Sabatini.

Represented on Gregory's ceiling is the entire cosmic realm, with the northern celestial hemisphere painted in the centre and the southern hemisphere on either side. Unlike the previous examples discussed, there is no reference to the patron's horoscope; like Raphael's fresco, the absence of the planets prevents such a reading. Additionally, because all of the constellations are depicted, there cannot be a general reference to a

10 See Janet Cox-Rearick, Dynasty and Destiny in Medici Art (Princeton: Princeton University Press, 1984), p. 30. Among the other astrologers employed by the Medici was Francesco Priuli, the same celestial advisor to Agostino Chigi.

${ }^{11}$ Claudia Rousseau, 'Cosimo I de Medici and Astrology: The Symbolism of Prophecy’ (PhD dissertation, Columbia University, 1993), p. 153. 
time of year, as seen in the Julian example. Instead, Vanosino illustrates the universe with the utmost accuracy: the relative positions of the individual stars, as well as those of the constellations, are for the first time in fresco each correctly plotted.

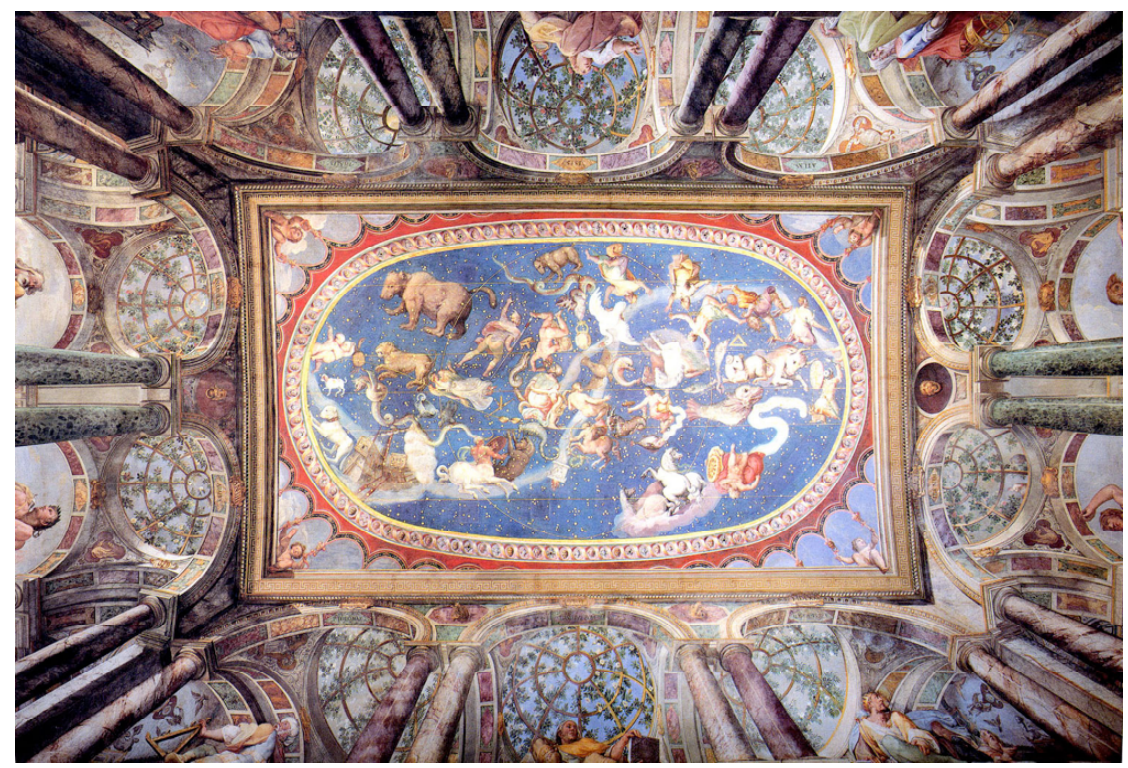

Figure 4. Giovanni Antonio Vanosino, Ottaviano Mascherino, and Lorenzo Sabatini, ceiling of the Sala Bologna. Commissioned by Pope Gregory XIII, 1575, Vatican Palace, Rome. Fresco. (photo: Archivio Fotografico, Musei Vaticani)

Among the group of Figures painted within the fictive colonnade is Marcus Manilius, on whom I would like to focus (Figure 5). Occupying the prominent location of front centre and depicted with balding hair and classical dress, the ancient Roman holds open a book with his right hand and props up a natal chart with his left. The glyphs on this tablet are legible, and such a deliberate detail is most certainly not arbitrary, nor do I believe it insignificant that it is depicted within the grasp of the founder of Renaissance astrological belief. According to Manilian theory then, I would like to suggest that this horoscope refers to Gregory himself. 
328 Depicting the Heavens: The Use of Astrology in the Frescoes of Renaissance Rome

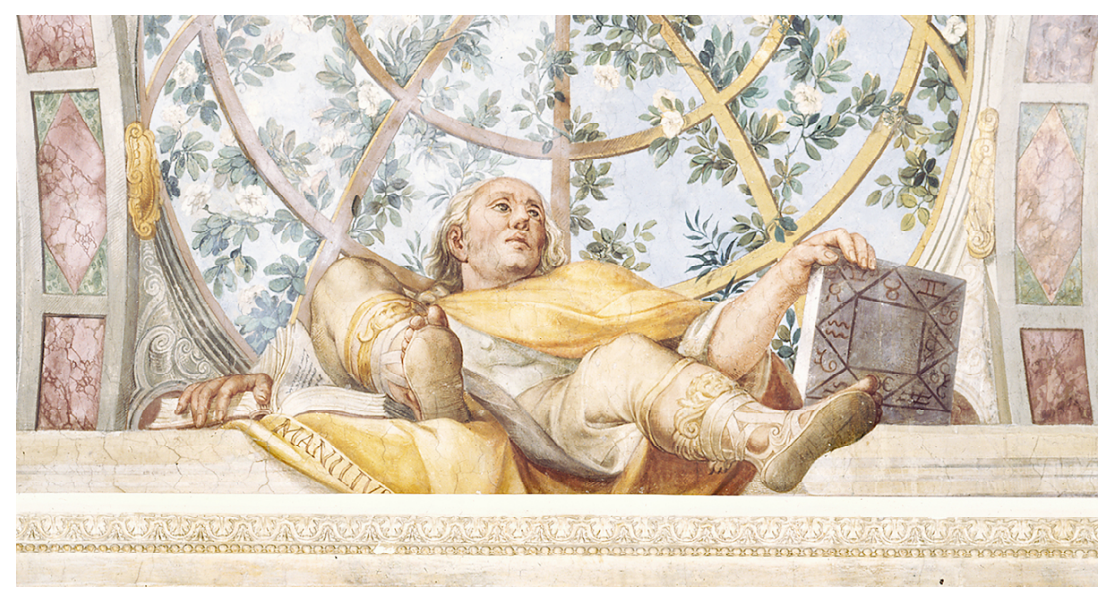

Figure 5. Lorenzo Sabatini, Marcus Manilius, detail of the ceiling in the Sala Bologna. (photo: Archivio Fotografico, Musei Vaticani)

Although a few of the glyphs are enigmatic in their representation, much can be gleaned from those that are clear. The most important of the signs here is Aquarius, located within the first house and therefore referencing its location on the ascendant. Describing those born under the water sign Manilius writes:

The youthful Waterman, who from upturned pot pours forth his stream, likewise bestows skills which have affinity with himself: how to divide springs under the ground and conduct them above, to transform the flow of water so as to spray the very stars, to mock the sea with man-made shores at the bidding of luxury, to construct different types of artificial lakes and rivers, and to support aloft for domestic use streams that come from afar... Never will the sons of Aquarius grow tired of the works which come in the wake of water and follow springs. They who issue from this sign are a gentle sort and a lovable breed, and no meanness of heart is theirs... ${ }^{12}$

According to the ancient astrologer, those born under Aquarius are able to control the waters of the world (metaphorically speaking) and are

${ }^{12}$ Manilius, Astronomica, Book 4, para. 259-272. 
primed for a life in which their alacrity for virtuous tasks is put to good use - traits any pontiff would celebrate and advertise.

Whether the placement of Aquarius on this chart refers to Gregory's birth or election is unclear; what can be determined with confidence, however, is that the water sign held special significance for the Bolognese pope. By the time the Sala Bologna was painted, astrological decoration was common practice, but the changing atmosphere in late sixteenth-century Rome necessitated that this pope downplay the horoscopic aspect of his fresco. Unlike the humanists Julius II and Leo X, Gregory XIII focused much of his attention on reform; further, because the Council of Trent condemned the use of judicial astrology, such a blatant reference to one's natal chart within the Vatican Palace was no longer appropriate. ${ }^{13}$ Moreover, as mentioned, the emphasis on this ceiling is given to cartographic accuracy, suggesting that the theme of Gregory's fresco is empirical astronomical investigation. Yet despite this, evidence that the pope still practiced astrology exists within the room's iconography, thus demonstrating how completely ingrained these beliefs were at the time.

To obtain a better understanding of the frescoes discussed, they should be explored within the larger tradition of celestial imagery. Just as it led to the renewal of astrological practice, it was with Renaissance humanism that images of the cosmos moved from the pages of personal medieval manuscripts to the walls and ceilings of both public and private buildings. In other words, these images were not kept within the confines of a manuscript to be seen only by a select few, but were instead painted in the permanent medium of fresco by some of the leading artists of the day. Each of the examples discussed demonstrates that such imagery was not reserved for the private chambers of the palace, but was instead commissioned for public rooms in which, according to the protocol of visitation, a number of viewers might bask in the celestial glory of the patron. The placement of this decoration therefore demonstrates that this type of pictorial aggrandizement was intended to reach a wide audience and was used by the patron as a form of visual self-promotion.

\footnotetext{
${ }^{13}$ In fact, Gregory's successor Sixtus V (1585-90), issued a papal bull in 1586 that further condemned the use of judicial astrology. On astrological practices and the Council of Trent, see Germana Ernst, 'Astrology, Religion and Politics in Counter-Reformation Rome', in Stephen Pumfrey (ed.), Science, Culture and Popular Belief in Renaissance Europe (Manchester: Manchester University Press, 1991), pp. 249-273; Corrine Mandel, "Starry Leo", the Sun, and the Astrological Foundations of Sixtine Rome', Racar 17 (1990): esp. p. 17.
}

Culture and Cosmos 
330 Depicting the Heavens: The Use of Astrology in the Frescoes of Renaissance Rome

The different ways in which a horoscope might be illustrated are also noteworthy. Although I have argued that the ceiling within the Sala di Galatea is the paradigmatic example, the emulation of its design was not always possible or appropriate. Certainly Leo adopted the general style and composition of Chigi's fresco, but what about Julius and Gregory? Leo's room within the Borgia suites provided a ceiling large enough for his artists to spread out all aspects of his horoscope, but the ceiling within the Stanza della Segnatura is much smaller, and thus prohibited such an expansive illustration. Further, although providing an ingenious visual compliment to Julius, Raphael's Figure of Astronomia is not the main subject of the library, and the image is therefore secondary to the overlying theme of the liberal arts. Finally, although Gregory's salon provided the immense ceiling space required for the grand style of the Farnesina, his support of empirical investigation and the reformatory atmosphere of late sixteenth-century Rome precluded such a depiction.

To conclude, it is worth mentioning that the widespread representation of this imagery is not unique to Rome, but that the above four examples represent a peak in the Renaissance. Beginning with Chigi's great expression of the renewed interest in judicial astrology concurrent with Renaissance humanism, celestial decoration flourished in the eternal city and elsewhere. The ancillary representation of Gregory's natal chart within the Sala Bologna demonstrates the pressures of the Council of Trent by late century, and that the ancient discipline of astrology, as well as the depictions of such, was in permanent decline. Indeed, by the time Urban VIII commissioned Andrea Sacchi to depict his horoscope within the Palazzo Barberini in 1629, the practice of the celestial sciences had diminished to such a degree, at least within the public realm, that the esoteric astrological subject within this fresco is still debated today. ${ }^{14}$

\footnotetext{
${ }^{14}$ This final statement in no way suggests that the depiction of astrological imagery comes to a stop after the Council of Trent, as there is much visual evidence to suggest the contrary. It is the specific depiction of one's horoscope or natal chart, however, which apparently falls from favor. For Sacchi's fresco see George Lechner, 'Tommaso Campanella and Andrea Sacchi's Fresco of Divina Sapienza in the Palazzo Barberini', The Art Bulletin 58 (1976): pp. 97108. It is now known that Urban was an avid practitioner of astrology, but again, he kept his investigations a secret.
} 